\title{
Challenging Factors Affecting Students' Speaking Performance
}

\author{
Y H Manurung 1 , S L Izar ${ }^{2}$ \\ \{yayukhayulina@umsu.ac.id ${ }^{1}$, srilistiana@umsu.ac.id $\left.{ }^{2}\right\}$ \\ ${ }^{1,2}$ University of Muhammadiyah Sumatera Utara, Jl. Kapten Muchtar Basri No.3, Glugur Darat II, \\ Kec. Medan Timur, Kota Medan, Sumatera Utara 20238, Indonesia
}

\begin{abstract}
This research was carried due to the lack of students' to achieve their fluency and proficiency in English speaking skill at English Department of University of Muhammadiyah Sumatera Utara. The present study aims to investigate the students' speaking problems and seeks the underlying factors contributing those matters. This research applied descriptive qualitative design by collecting the documents, observation and interview data. Then the data was analyzed by using qualitative data analysis with Miles and Huberman data analysis by covering data collection, data display and conclusion drawing/verification. The was data obtained from the questionnaire with 125 EFL second year students, individual interviews with lecturers, and class observation. The result showed internal factors surprisingly dominated the difficulties in their speaking peerfomance namely the students' lack of vocabulary and their hesistance or reluctant feeling of making mistake and being afraid to be. However it will matter a lot for them if the lecturers conduct the suitable teaching approaches by helping the peers, and classroom organization.
\end{abstract}

Keywords: challenging,factors, speaking, performance

\section{Introduction}

In Indonesia studying English as foreign language is fundamental for the necessity presented in this globalized world since science and technology are the world culture and the means to acquire and keep up with the development of science and technology. Speaking English tends to be the most important skills of all the four skills because people who know a language are usually referred to as speakers of that language. In Indonesia, the achievement of English speaking proficiency has been more and more concerned by most English-majored graduate for its indispensable role in international communication relationships arisen from the recent trend of global integration. Such the impact has brought about the fluency and proficiency of English speaking skills as one main objective in curriculum of English language program at most universities especially in English education program. But the fact showed that it is still challenging for numerous English language undergraduates to fully achieve speaking skills, especially for second-year students in University of Muhammadiyah Sumatera Utara, Indonesia.

A number of empirical studies have examined the same research concern related to difficulties encountered by university EFL students while participating in oral classroom activities. For example (V.P., H.T., \& P.T.M., 2018) studies the major difficulty revealed by the participants is lacking vocabulary to express ideas in speaking English with over two third 
of agreed responses (79.4\%). Another problem agreed by nearly $65 \%$ is the limitation of English speaking strategies. The study then pointed that both teachers and learners indicated that lack of vocabulary is one of the major factors in students' inability to speaking English (Khan, Radzuan, Shahbaz, Ibrahim, \& Mustafa, 2018) found that. Another study by (Al-Jamal \& Al-Jamal, 2013) investigated the difficulties that may be encountered at six Jordanian public universities by collecting the data from a survey questionnaire and semi-structured interviews and revealed that most student participants faced challenges with the limitation of oral skill, lack of speaking time, and crowded classes as the most highlighted factors. (Ariyanti, 2016) examined that psychological barriers also appear in discussion session, where in this case some students do not want to participate because they are too afraid of making mistakes, lack of self-esteem and motivation so they prefer to keep silent in the class.

The findings emphasised the challenges with regard to (1) learners' issues such as lacking vocabulary and limitation of English speaking strategies; (2) learner' limitation of oral skill, lack of speaking time, and crowded classes; and (3) learners‘ psychological barriers. Specifically, the findings similarly analysed challenges stemmed from learners' weaknesses in speaking English and proposed the necessity of lecturers' ready supports by diversifying their teaching activities. Since research on this aspect in Indonesian universities settings has been sparse, this study intends to adjust those findings and proposes the necessity of lecturers' ready supports by diversifying their teaching activities.

Consequently, with regard to helping English-majored students learn speaking skills more effectively, the current research is aimed to explore that promote or hinder the students speaking performance and possible measures to tackle such challenges. 


\section{Method}

This descriptive qualitative research aims to investigate the students' speaking problems and seeks the underlying factors contributing those matters. The subject of the study was 125 EFL English department students on te second year of University of Muhammadiyah Sumatera Utara, Medan in the first academic year of 2018/2019. For the purpose of this study, the researchers conducted a. Close observation technique, the researcher acted as nonparticipant observer and didn't participate and interfere in teaching speaking subject. A checklist was also given each time they face challenges during guided English conversation $b$. Video and audio recording, every activity among lecturer and students was recorded c. Interview technique, which was used to seek the barriers appeared during conversationThe students were given 6 questions relating difficulties related to students ${ }^{6}$ internal factors in speaking perfomance and 6 questions relating to extrenal factors refering how the lecturers taught them. Furthermore the research data was analyzed by using qualitative analysis, code data and look for themes related to the research focus. In analyzing the data, the researcher concerned with the components of data analysis in interactive model proposed by Miles and Huberman (1994).

\section{Findings and Discussion}

The result showed the difficulties related to internal factors of EFL English department students $(n=125)$ for the present study comprised on a 3-point Likert scale, ranging from agree (1), not sure (2), disagree

\subsection{Difficulties related to internal factorsof EFL students}

The table below showed the factors as the students' challenges in their speaking performance

Table 1. Difficulties related to internal factors $(n=125)$

\begin{tabular}{lccc} 
When speaking English, ... & Agree \% & $\begin{array}{c}\text { Not sure } \\
\text { \% }\end{array}$ & Disagree \% \\
\hline I lack vocabulary to express ideas & 82.1 & 12.3 & 5.6 \\
I do not know English speaking strategies & 60.7 & 32.7 & 6.6 \\
I have limited chances to involve speaking activities & 25.4 & 43.2 & 31.4 \\
I lack motivation in speaking English with classmates & 31.2 & 28.9 & 39.9 \\
I feel afraid of making mistakes and being criticised by classmates & 69.2 & 27.8 & 3 \\
I feel shy & 54.4 & 28.2 & 17.4 \\
Mean value & 57.55 & 28.55 & 12 \\
\hline
\end{tabular}


Based on the table 1 above showed challenges faced the EFL students themselves in speaking performance related to the internal and external factors . For the first type factor, lacking vocabulary in expressing their idea placed as the major challenge with the percentage of 82.1 Another problem agreed by $62 \%$ is their hesistance or reluctant feeling of making mistake and being afraid to be critized as their internal factors. However, the difficult factor dealing with limited chances to get involved speaking activities gets fewer responses with only $31.2 \%$. Significantly, most of them agreed with lacking vocabulary as the significant hindering factor $(82.1 \%)$ (Table 4$)$.

The findings are in line with those of the previous studies (Al-Jamal \& Al-Jamal, 2013) and (Ariyanti, 2016) (Cabe \& Selatan, 2012) regarding the lack of vocabualry, confidence and motivation as inhibiting challenges for EFL students in their performance in speaking

\subsection{Difficulties related to external factors of EFL students}

Regarding the second type of factor, in the current study; there were several external factors investigated namely lecturerer's teaching method, teaching curriculum and syllabus, in-class learning environment and extra -curriculuma activities. The table 2 showed those factors as the barriers that exisisted as the external factors coming from outside of EFL students.

Table 2. Challenges as the external factors related to the lecturers' teaching method, teaching curriculum and syllabus, in-class learning environment and extra curriculuma activities

\begin{tabular}{|c|c|c|c|}
\hline Statements & Agree \% & $\begin{array}{l}\text { Not sure } \\
\quad \%\end{array}$ & Disagree \% \\
\hline $\begin{array}{l}\text { When learning English speaking skills, i find that lecturers did not } \\
\text { create interesting activities in class }\end{array}$ & 5.1 & 21.5 & 73.4 \\
\hline $\begin{array}{l}\text { When learning English speaking skills, i find that Lecturers did not } \\
\text { correct mistakes of speaking }\end{array}$ & 19.4 & 20.1 & 60.5 \\
\hline $\begin{array}{l}\text { I find that teaching curriculum limit learners' English speaking } \\
\text { practice }\end{array}$ & 23 & 15 & 62 \\
\hline $\begin{array}{l}\text { I find that the assessment of speaking practice was not regularly } \\
\text { applied }\end{array}$ & 22.1 & 6 & 71.9 \\
\hline $\begin{array}{l}\text { I find that the number of native teachers in language skill classes is } \\
\text { limited }\end{array}$ & 18 & 34.2 & 47.8 \\
\hline $\begin{array}{l}\text { I find that some of better students dominate speaking English in } \\
\text { class }\end{array}$ & 12 & 40.9 & 47.1 \\
\hline
\end{tabular}


As indicated in Table 2, most student respondents disagreed with the difficulties caused by their lecturers' teaching methods with the disagreed responses which were much higher than the agreed ones. In particular, the same percentage of student respondents highly disagreed with their lecturers. The interviewed lecturers also confirmed their teaching methods which were not appropriate for all students in speaking classes. Then referring to teaching curriculum and syllabus, the findings from lecturers' interviews and focus group interviews revealed that the participant diagrees that lecturers' teaching curriculum limit learners' English speaking practice. it is proven by $62 \%$ disagrees with that statament and significantly the participants' response to disagreement reveales $71.9 \%$ to the assessment of speaking practice was not regularly applied. The interviewed participants also mentioned limited number of native teachers in language skill classes as the most challenging external factor for students' speaking performance. Additionally, the class observations indicated that the results of interviews with lecturers and students shared the same findings as those of the survey questionnaire with respect to crowded classes and immovable tables and chairs which prevented students' speaking performance.

These findings are in line with the previous studies (Huang, 2010; Sime \& Priestley, 2005; Souriyavongsa, Rany, Jafre Zainol Abidin, \& Lai Mei, 2013) in terms of hindering factors for students' speaking practice. The role of vocabulary mastery in speaking developlement owned by EFL students and their hesistance or reluctant feeling of making mistake and being afraid to be critized as their internal factor in university of Muhammadiyah Sumatera Utara placed as the dominat factors as challenged as in line with the previous study (Khan et al., 2018) (Ariyanti, 2016) (Andrade, 2006; Breckler, Teoh, \& Role, 2011)(Sime \& Priestley, 2005) and significantly the external factors related to the lecturers' teaching method, teaching curriculum and syllabus, in-class learning environment and extra -curriculuma activities contributes less than internal factors of EFL students.

\section{Conclusion}

The current study with EFL students of University of Muhammadiyah Sumatera Utara shows that the challenges faced by them in speaking perfomances caused dominantly by two factors namely internal and external factors. Internal factors which are related to learners themselves while external factors regarding lecturers' teaching methods, teaching curriculum and syllabus, in-class English learning environment, and extra-curriculum activities. Internal factors surprisingly dominated as the challenges from other factors, namely students' lack of vocabulary and English speaking strategies, limited number of native teachers, limited English speaking environment. With regard to external factors, the following concerns are recommended. First of all, it is recommended that should flexibly apply different teaching strategies that may reduce their use of mother tongue in their classes such as integrating various speaking performance, updating information related to English programs, cooperating with other lecturers of language skills to organise more English programs and share teaching experiences. After that the university and the school administrators should reconsider the improvement of curriculum and syllabus regarding teaching textbook to provide students with frequent opportunities of speaking supported by the good facilities. 
Regarding internal factors, the researchers recommend the EFL students need to get more activeness in independent learning style and having better critical thinking that in line with their speaking performance. Joing Engish speaking club and engllish debate society significantly assisting them great in buidling their confidence in speaking. In additong, there should be studied to find out the updated starategies or methos in teaching Engllish speaking.

\section{Acknowledgments}

This research was supported/partially supported by University of Muhammadiyah Sumatera Utara. We thank you for the head of English education departemant who provided insight, expertise and comment for improving this research. We would also like to show our gratitude to the EFL students on the second year for patricpating suring this research.

\section{References}

[1] Al-Jamal, D. A., \& Al-Jamal, G. A. (2013). An investigation of the difficulties faced by EFL undergraduates in speaking skills. English Language Teaching. https://doi.org/10.5539/elt.v7n1p19

[2] Andrade, M. S. (2006). International students in English-speaking universities: Adjustment factors. Journal of Research in International Education. https://doi.org/10.1177/1475240906065589

[3] Ariyanti, A. (2016). Psychological Factors Affecting EFL Students' Speaking Performance. ASIAN TEFL Journal of Language Teaching and Applied Linguistics. https://doi.org/10.21462/asiantefl.v1i1.14

[4] Breckler, J., Teoh, C. S., \& Role, K. (2011). Academic Performance and Learning Style Self-Predictions by Second Language Students in an Introductory Biology Course. Journal of the Scholarship of Teaching and Learning.

[5] Cabe, P., \& Selatan, T. (2012). Psychological Factors That Hinder Students from Speaking in English Class ( A Case Study in a Senior High School in South. Journal of Education and Practice.

[6] Huang, C. (2010). Exploring factors affecting the use of Oral Communication Strategies. Lunghwa University of Science and Technology.

[7] Khan, R., Radzuan, N., Shahbaz, M., Ibrahim, A., \& Mustafa, G. (2018). The Role of Vocabulary Knowledge in Speaking Development of Saudi EFL Learners. Arab World English Journal. https://doi.org/10.24093/awej/vol9no1.28

[8] Sime, D., \& Priestley, M. (2005). Student teachers' first reflections on information and communications technology and classroom learning: Implications for initial teacher education. Journal of Computer Assisted Learning. https://doi.org/10.1111/j.13652729.2005.00120.x

[9] Souriyavongsa, T., Rany, S., Jafre Zainol Abidin, M., \& Lai Mei, L. (2013). Factors Causes Students Low English Language Learning: A Case Study in the National University of Laos. International Journal of English Language Education. https://doi.org/10.5296/ijele.v1i1.3100

[10] V.P., Q., H.T., N., \& P.T.M., N. (2018). Challenges to speaking skills encountered by English-majored students: A story of one Vietnamese university in the Mekong Delta. Can Tho University Journal of Science, 54(5)(5), 38. https://doi.org/10.22144/ctu.jen.2018.022 
